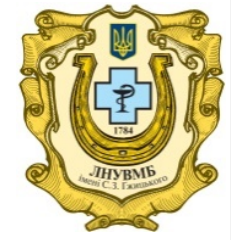

Ukrainian Journal of

Veterinary and Agricultural Sciences

http://ujvas.com.ua

Stepan Gzhytskyi National University of Veterinary Medicine and Biotechnologies Lviv

original article $\mid$ UDC 637.5:619:614.48:615.28:637.513 | doi: 10.32718/ujvas1-1.02

Volume 1

Number 1

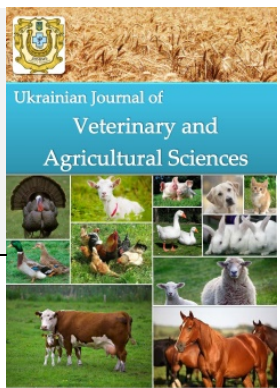

\title{
Activity of washing-disinfecting means "San-active" for sanitary treatment of equipment of meat processing enterprises in laboratory and manufacturing conditions
}

\author{
V. Salata ${ }^{1}$, M. Kukhtyn ${ }^{2}$, Yu. Pekriy ${ }^{2}$, Yu. Horiuk ${ }^{3}$, V. Horiuk ${ }^{3}$ \\ ${ }^{1}$ Stepan Gzhytskyi National University of Veterinary Medicine and Biotechnologies Lviv, Pekarska Str., 50, Lviv, 79010, Ukraine \\ ${ }^{2}$ Ternopil Research Station of the Institute of Veterinary Medicine NAAS, Trolleybusna Str., 12, Ternopil, 46027, Ukraine \\ ${ }^{3}$ State Agrarian and Engineering University in Podilya, Shevchenko Str., 13, Kamyanets-Podilsky, 32300, Ukraine
}

\begin{abstract}
Article info
Received 02.04.2018

Received in revised form 30.05.2018

Accepted 01.06.2018

Correspondence author

Volodymyr Salata

Tel.: +38-067-728-89-33

E-mail: salatavolod@ukr.net

(C) 2018 Salata V. et al. This is an open-access article distributed under the terms of the Creative Commons Attribution License, which permits unrestricted use, distribution, and reproduction in any medium, provided the original author and source are credited.

\section{$(\mathrm{cc}) \mathrm{BY}$}

Abstract

The article presents the results of the research of the new detergent agent "San-active" for meat processing enterprises. It was established that "San-active" in the concentration from 0.3 to $2.0 \%$ is moderately alkaline (concentration of hydrogen ions is $11.44-12.7$ ), at a concentration of $2.5 \%$ and above, with very alkaline $\mathrm{pH} \geq 13.11$ units. In the "San-active" detergent, at the concentration from 0.3 to $2.5 \%$, the surface tension is $34.97-28.24 \mathrm{mN} / \mathrm{m}$. The absorbability of the parts of the technological equipment with the solutions of the "San-active" means sharply increases with increasing concentration. At the temperature of solutions of the medium $19.0 \pm 1.0^{\circ} \mathrm{C}$ the angle of wetting decreases from 69.8 degrees. at a concentration of $0.3 \%$ to 50.5 degrees. at a concentration of $2.5 \%$ (in 1.4 times). It has been established that "San-active" in $0.5 \%$ concentration provides the bactericidal effect on test cultures of conditionally pathogenic bacteria, spore-forming microorganisms and fungi. The "San-active" agent at $0.5 \%$ concentration is bactericidal to $S$. aureus and E. faecalis cells that are in a biofilm in 10 minutes of exposition. For the inactivation of $E$. coli and P. aeruginosa cells in a biofilm, it is necessary that the "San-active" acts in a concentration not lower than $0.5 \%$ and not less than 30 minutes. The agent shows a washing effect on the evaluation of "good" at $0.5 \%$ concentration, and $1.0 \%$ and above the concentration on the score "excellent". "San-active" in the concentration from 1.0 to $2.0 \%$ shows very weak corrosion activity on stainless steel. The use of "Sanactive" detergent for the sanitary treatment of equipment surfaces in the intestinal workshop at the concentration of the working solution $1.0-2.0 \%$ and the temperature $60 \pm 5{ }^{\circ} \mathrm{C}$ for 20 minutes provides $99.9-100 \%$ efficiency of sanitary treatment.
\end{abstract}

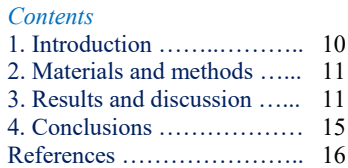

Key words: bactericidal action, corrosion, sanitary treatment, "San-active" agent, meat-processing enterprises.

\section{Citation:}

Salata, V., Kukhtyn, M., Pekriy, Yu., Horiuk, Yu., \& Horiuk, V. (2018). Activity of washing-disinfecting means "San-active" for sanitary treatment of equipment of meat processing enterprises in laboratory and manufacturing conditions. Ukrainian Journal of Veterinary and Agricultural Sciences, 1(1), 10-16.

\section{Introduction}

An important condition for the production of products of animal origin, in particular meat and meat products, is the careful sanitation of processing equipment throughout the entire range from slaughter to the packaging and storage of the product. (Jessen and Lammert, 2003; Sun, 2014; Marriott et al., 2018). Technological equipment must be subjected to such sanitary treatment, in which the "residual" microflora would not affect the safety and quality indicators of the raw material and the finished product (Abdallah et al., 2014; Kukhtyn et al., 2017). Thus, in accordance with the recommendations on sanitary-microbiological study of flushing out of surfaces of objects of veterinary supervision and control, in samples taken from equipment at meat-packing plants and slaughter enterprises, the total number of microorganisms in $1 \mathrm{~cm}^{3}$ of washings, taken from $100 \mathrm{~cm}^{2}$ of the area should not exceed $1000 \mathrm{CFUs}$, and the TBC titre should be greater than 1.0 (Bekker et al., 2011). In order to ensure the compliance with the microbiological indicators of the sanitary state of objects, the careful sanitation of all equipment using modern detergents and disinfectants should be carried out (Varzakas and Tzia, 2015; Kukhtyn et al., 2017; Kovalenko et al., 2018). There are such disinfectants for meat industry on the Ukrainian market as: "Virosan", "Bioclore", "Catryl-Dez" and detergents "Santana", "Bioshaum", "Chistoprom" and others. There are practically no remedies for combined washing-disinfectant agents, there are only disinfectants with a cleansing effect, in particular, "Chlorantoin". The importance of developing of washing- 
disinfectants is that they combine two important properties washing and disinfection (Knape et al., 2015; Meireles et al., 2016). This is exactly why "San-active", a washingdisinfectant, was developed by us, which active substances are CHAS, surfactants, alkali, complexones and corrosion inhibitors.

The purpose of the work was to investigate the bactericidal properties of the "San-active" agent in relation to test cultures of conditionally pathogenic bacteria, spore-forming microorganisms and fungi; cleaning properties and corrosion of stainless steel to determine the efficiency of sanitary treatment of technological equipment in the intestine workshop of meat processing enterprises.

\section{Materials and methods}

When determining the solubility of the washingdisinfective agent "San-active", $50 \mathrm{~cm} 3$ of the agent in small portions of $10 \mathrm{~cm}^{3}$ was introduced into a glass cylinder of $50 \mathrm{~cm}^{3}$ of distilled water, stirring constantly with a glass rod. The solubility of the substance in $\mathrm{cm}^{3}$ per $100 \mathrm{~cm}^{3}$ of water was determined by the formula:

$$
X=\frac{\left(P-P_{1}\right) \times 100}{O}, \text { where }
$$

$P$ - number of the researched agent taken in the experiment, $\left(\mathrm{cm}^{3}\right)$;

$P_{1}-$ remains of the agent after the experiment, $\left(\mathrm{cm}^{3}\right)$;

$o$ - volume of solvent, $\left(\mathrm{cm}^{3}\right)$.

The research on the determination of the surface tension of the solutions of the "San-active" solution was carried out with the aid of the Traube stamagumometer.

The research on the determination of the foaming capacity of the solutions of the "San-active" agent was carried out using the Ross-Miles device, and the results obtained in percentages were calculated using the formula:

$$
X=\frac{H_{0} \times 100}{H}
$$

where, $H_{0}$ - initial foam volume (mm);

$H$ - column height of the investigated solution, (mm).

The resistance of the foam was determined by the formula:

$$
\dot{O}=\frac{\dot{I}_{10}}{\dot{I}_{0}}
$$

where, $H_{10}$ - reduction of foam for 10 minutes.

Investigation of the wetting capacity of solutions of the "San-active" was carried out by measuring the marginal angle of wetting on the boundary between the phase separation of the solution-air-solid surface using the X-13 device at a temperature of $19 \pm 1^{\circ} \mathrm{C}$ and $55 \pm 5^{\circ} \mathrm{C}$.

Determination of the bactericidal concentration of the "San-active" agent was carried out using E. coli, P. aeruginosa, S. aureus, E. faecalis, B.cereus, B. subtillis, Candida spp. and Penicillium spp test cultures. Additionally, cultures were tested for temperature stability, phenol and chloramine (Kukhtyn et al., 2017). The daily culture bacteria were prepared in a $0.85 \%$ solution of sodium chloride containing bacterial cells of $1 \mathrm{bcm} / \mathrm{cm}^{3}$ according to the optical standard of turbidity. Different concentrations of solutions were prepared from the detergent and disinfectant, they were introduced in $10 \mathrm{~cm}^{3}$ of a Flourinsky jar and heated to a temperature of $+60 \pm 5{ }^{\circ} \mathrm{C}$ in a water bath. $0.1 \mathrm{~cm}^{3}$ of 1 billion bacterial cells were injected to concentrations of the substance. The compound was stirred and after 10, 20, and 30 minutes, $1 \mathrm{~cm}^{3}$ of solution was taken and put into Petri cups filled with $15 \mathrm{~cm}^{3}$ of nutrient medium. The presence of microorganisms of test cultures after the action of the detergent and disinfectant was determined according to generally accepted methods in microbiology. The control was $0.3 \%$ of the working solution of chloranthine. Exposure of 10, 20 and 30 minutes was chosen depending on the time, which is usually spent on the processing of milking equipment in the production environment.

The degree of corrosion activity was determined according to the generally accepted method. Samples of metals were used in the experiments, from which the technological equipment of the meat processing enterprises was manufactured: aluminum, stainless and zinced steel, sizes $50 \times 20$ $\mathrm{mm}$ and thickness from 1 to $4 \mathrm{~mm}$.

The determination of the washing effect was carried out on plates of stainless steel and glass size $10 \times 10 \mathrm{~cm}^{2}$. The surface of these plates was pre-applied with a layer of pork fat (mist), which was added $10 \%$ of soot and dried at room temperature for two days. Then, using a gauze swab, the plates were washed with the investigated agents. The evaluation of the results was made visually, paying attention to the level of cleanliness of the plates according to the following criteria:

- absence of washing effect, estimation "bad" - the surface of the plates dirty, fatty;

- wash effect is "insignificant" - the surface of the plates is cloudy, oily, it is possible to have single particles of contamination;

- mark "good" - the surface of the plates has a clean appearance, but after rinsing, the water is collected in a drop, when the liquid is applied, to indicate the fatty film appear yellow spots or streaks of colored fat;

- mark "excellent" - the surfaces of the plates are clean, wettability is uniform, even after applying the liquid to indicate the fatty film, the absence of yellow stains and bands.

The obtained research results were processed statistically using programs Microsoft Excel and Statistics 6. The difference was considered probable at $\mathrm{P} \leq 0.05 ; \mathrm{P} \leq 0.01$ and $\mathrm{P} \leq 0.001$.

\section{Results and discussion}

Studies are needed in the development of detergents for the food industry to determine the solubility and dissolution rates (Da Costa Luciano et al., 2016). All detergents should be readily dissolved in water to prevent sediment deposition on the surfaces of technological equipment parts (Le Maire et al., 2000; Seddon et al., 2004; Kowalska, 2016). Therefore, at the dissolution rate, washing-disinfectants are divided into fast-dissolving - dissolution time of 5 minutes, wellsoluble - from 6 to 15 minutes and slowly soluble - more than 15 minutes.

We have found that at a temperature of $19 \pm 1{ }^{\circ} \mathrm{C}$ and $55 \pm 5{ }^{\circ} \mathrm{C}$ the solubility of the "San-Active" was 100 , and in the time of dissolution it turned out to be rapidly soluble, the solution dissolved for 30 minutes. This indicates that the detergent can be used under normal production conditions and dissolve at a temperature of $19 \pm 1{ }^{\circ} \mathrm{C}$ and at a temperature of $55 \pm 5^{\circ} \mathrm{C}$.

In order to separate fat deposits on surfaces of the technological equipment and objects of the environment of slaughter shops and meat processing enterprises, it is neces- 
sary that the agents show good sinking property that depends on the $\mathrm{pH}$ of solutions (Cazelle et al., 2015).

Fig. 1 shows the dependence of the $\mathrm{pH}$ of solutions of the "San-active" on its concentration.

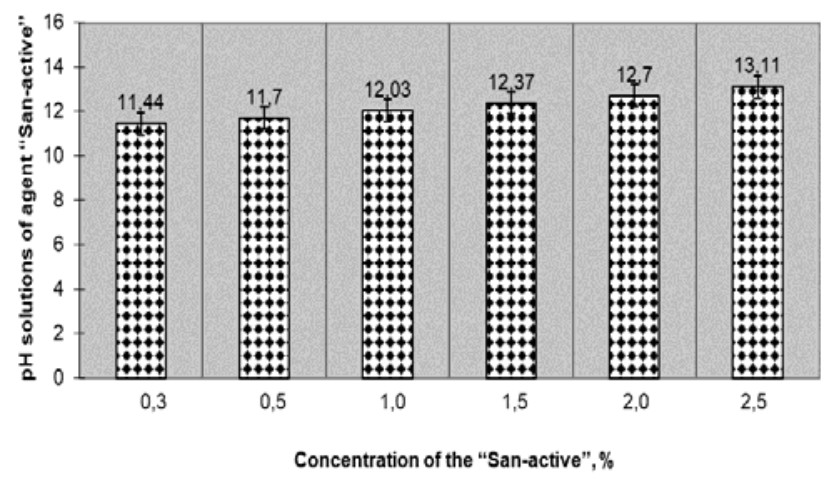

Fig. 1. pH solutions of agent "San-active" depending on its concentration

As it can be seen from the data in Fig. 1 solutions of the "San-active" agent at a concentration of 0.3 to $2.0 \%$ were moderately alkaline (concentration of hydrogen ions was $11.44-12.7$ ), at a concentration of $2.5 \%$ and above, a very alkaline $\mathrm{pH} \leq 13.11$ units. This indicates that such concentrations will have a good hydrolysis of fats.

It was found that the surface tension of distilled water is $72.72 \pm 0.15 \mathrm{mN} / \mathrm{m}$. In solutions of detergents and washingdisinfectants, surface tension should be lower, compared with water (Li et al., 2015). According to normative documents, the value of the surface tension for solutions of detergents and washing-disinfectants, used for sanitary treatment of technological equipment at food industry enterprises, should not exceed $60 \mathrm{mN} / \mathrm{m}$.

Fig. 2 shows results of investigations of the surface tension of solutions "San-active", depending on its concentration.

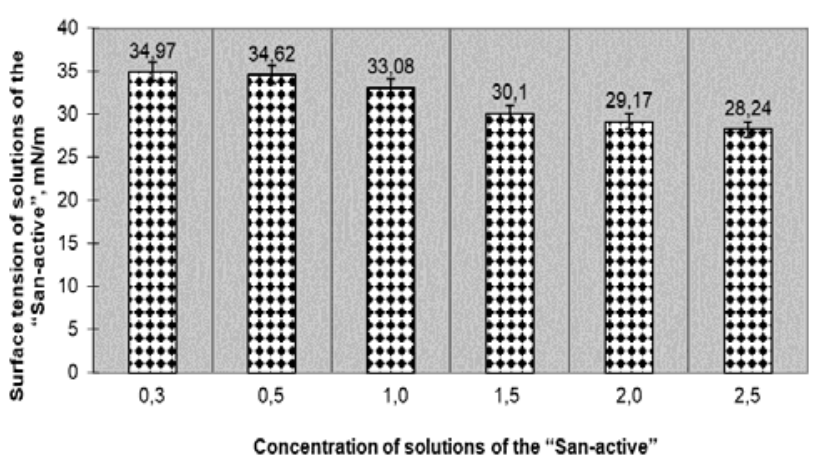

Fig. 2. Surface tension of solutions of the "San-active" depending on its concentration

As can be seen from the data shown in Fig. 2, that with increasing concentration of solutions of the "San-active" solution, there is a decrease of the surface tension. In the "San-active", at a concentration of $0.3 \%$, the surface tension was $34.97 \mathrm{mN} / \mathrm{m}$. It is evident from this fact that solution of the detergent in the concentration of $0.3 \%$ and above have good washing properties.

In order to ensure the maximum washing effect of the working surfaces of processing equipment, it is necessary that the concentration of detergents and washingdisinfecting means has sufficiently wetting property (Yao and He, 2014). In accordance with the requirements for detergents and washing-disinfectants for the sanitary treatment of processing equipment, the marginal angle of wetting should not be more than $90 \%$. Therefore, a dissolved detergent or washing-disinfectant is a liquid with a reduced surface tension, which has the best wetting and washing properties.

The results of studies on the wetting capacity of the solutions of the "San-active" are shown in Fig. 3

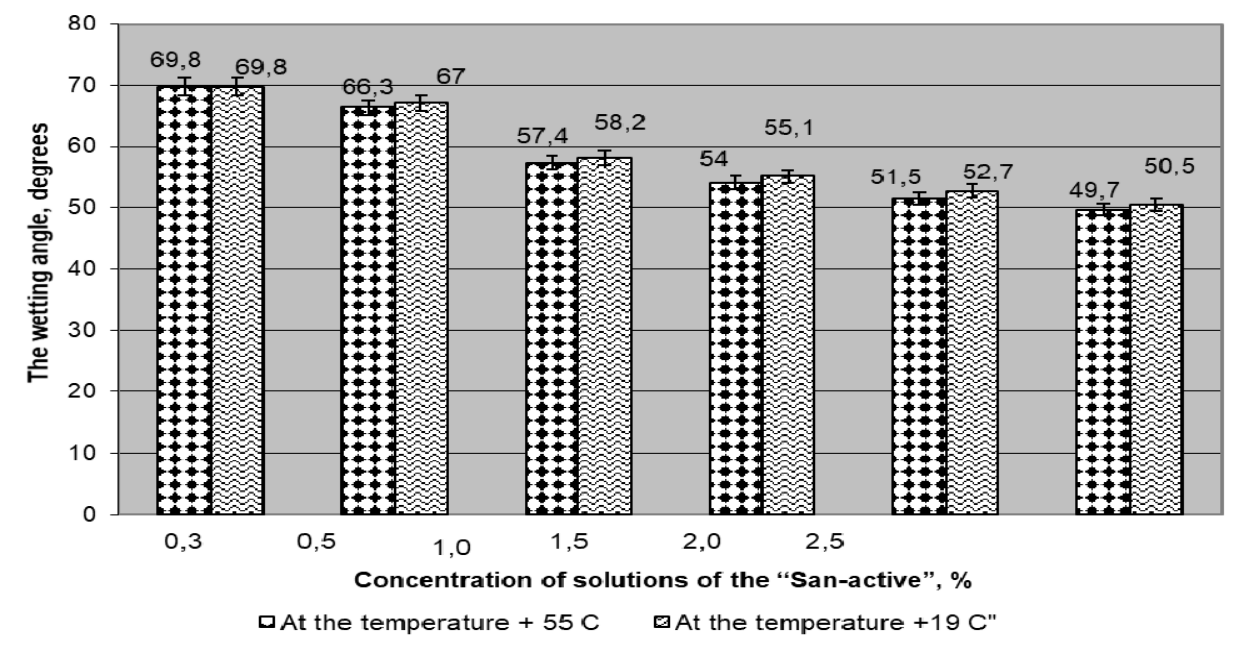

Fig. 3. The wetting ability of solutions of the "San-active" depending on its concentration

As can be seen from the abovegiven data, the wettability of the parts of the technological equipment with solutions of the "San-active" will sharply increase with increasing concentrations. At the temperature of the solutions of the detergent $19 \pm 1{ }^{\circ} \mathrm{C}$, the wetting angle increased from $69.8 \mathrm{de}-$ grees at a concentration of $0.3 \%$ of the detergent to
50.5 degrees at a concentration of $2.5 \%$, i.e. in 1.4 times $(\mathrm{P} \leq 0.01)$.

An increase in the temperature of solutions of the "Sanactive" to $55 \pm 5{ }^{\circ} \mathrm{C}$ contributed to a growth of the wetting capacity by 1-1.5 degrees, compared with a temperature of $19 \pm 1{ }^{\circ} \mathrm{C}$. 
Consequently, solutions of the "San-active" detergent, starting with $0.3 \%$ concentration, significantly increase the wettability of the surface.

During the sanitary treatment of processing equipment in the meat industry, detergents and washing-disinfectants with moderate foaming are used. If the detergents exhibit high foaming capacity, the washing process does not provide dissolving of contaminants.

The washing-disinfecting agent "San-active" showed a stronger antimicrobial effect on the gram-positive coccal form of the microflora, compared to gram-negative (Table 1).

\section{Table 1}

Influence of the "San-active" on the test culture of conditional-pathogenic bacteria in the suspension method, $\mathrm{n}=36$

\begin{tabular}{|c|c|c|c|c|c|c|c|c|c|c|c|c|c|}
\hline \multirow{4}{*}{ Name of the agent } & \multirow{4}{*}{$\begin{array}{l}\text { Concentra- } \\
\text { tion, } \%\end{array}$} & \multicolumn{12}{|c|}{ Test cultures of microorganisms } \\
\hline & & \multicolumn{3}{|c|}{ S. aureus } & \multicolumn{3}{|c|}{ E. faecalis } & \multicolumn{3}{|c|}{ E. coli } & \multicolumn{3}{|c|}{ P. aeruginosa } \\
\hline & & \multicolumn{12}{|c|}{ The duration of the agent action, $\min$} \\
\hline & & 10 & 20 & 30 & 10 & 20 & 30 & 10 & 20 & 30 & 10 & 20 & 30 \\
\hline \multirow{4}{*}{ San-active } & 0.1 & + & + & + & + & + & + & - & + & + & - & + & + \\
\hline & 0.5 & + & + & + & + & + & + & + & + & + & + & + & + \\
\hline & 1.0 & + & + & + & + & + & + & + & + & + & + & + & + \\
\hline & 1.5 & + & + & + & + & + & + & + & + & + & + & + & + \\
\hline Chloranthine & 0.3 & - & + & + & - & + & + & - & + & + & - & + & + \\
\hline
\end{tabular}

Notes: "+" - bactericidal action; "-" - absence of bactericidal action

The bactericidal action on bacteria $S$. aureus and E. faecalis was observed in 10 minutes at $0.1 \%$ concentration. During this time, at a concentration of $0.1 \%$, the agent did not inactivate the microorganisms of the E. coli and Pseudomonas aeruginosa. The bactericidal effect on the Pseudomonas aeruginosa and E. coli, at the same concentration, manifested after 20 minutes of action of the detergent. "Sanactive", in a concentration of $0.5 \%$, provided bactericidal effect on all types of conditional-pathogenic bacteria taken in the experiment after 10 minutes of contact with microorganisms.
The detergent "Chloranthine" in the concentration according to the instructions for use, showed a bactericidal effect on all conditional-pathogenetic microorganisms in 20 minutes of an action.

The "San-active" agent at a concentration of $0.1 \%$ showed no bactericidal effect on spore-forming microorganisms $B$. cereus, B. subtillis, and fungi of genus Penicillium for 30 minutes. However, at this concentration and 30 minute action, the agent inactivated the Candida spp. Fungi. (Table 2).

Table 2

Influence of "San-active" on spore-forming and fungal microflora in the suspension method, $\mathrm{n}=36$

\begin{tabular}{|c|c|c|c|c|c|c|c|c|c|c|c|c|c|}
\hline \multirow{4}{*}{ Name of the agent } & \multirow{4}{*}{$\begin{array}{l}\text { Concentra- } \\
\text { tion, } \%\end{array}$} & \multicolumn{12}{|c|}{ Test culture of microorganisms } \\
\hline & & \multicolumn{3}{|c|}{ B. subtillis } & \multicolumn{3}{|c|}{ B. cereus } & \multicolumn{3}{|c|}{ Candida spp. } & \multicolumn{3}{|c|}{ Penicillium spp. } \\
\hline & & \multicolumn{12}{|c|}{ The duration of the agent action, min } \\
\hline & & 10 & 20 & 30 & 10 & 20 & 30 & 10 & 20 & 30 & 10 & 20 & 30 \\
\hline \multirow{4}{*}{ San-active } & 0.1 & - & - & - & - & - & + & - & - & + & - & - & - \\
\hline & 0.5 & - & - & + & - & - & + & + & + & + & - & + & + \\
\hline & 1.0 & + & + & + & + & + & + & + & + & + & + & + & + \\
\hline & 1.5 & + & + & + & + & + & + & + & + & + & + & + & + \\
\hline Chloranthine & 0.3 & - & - & + & - & - & + & - & - & + & - & - & - \\
\hline
\end{tabular}

Notes: "+" - bactericidal action; “_"- - absence of bactericidal action

At the same time, a $0.5 \%$ solution of the agent showed a bactericidal effect on spore-forming microflora after 30 minutes, on fungi of genus Penicillium - after 20 minutes, and on yeast of the genus Candida - for 10 minutes.

Starting from $1.0 \%$ concentration, the "San-active" agent provided a bactericidal effect on spore-forming and fungal microflora for 10 minutes. The bactericidal action of the "Chloranthine" was similar to that of the "San-active" in $0.1 \%$ concentration.

According to the results of many studies, microorganisms have a major part of their existence in the environment in a self-generated protein-polysaccharide biofilm that protects them from environmental factors (Burmolle et al., 2006; Langsrud et al., 2016; Moretro and Langsrud, 2017). The planktonic form of its existence is used by microorganisms only for the colonization of other environmental ob- jects (Abee et al., 2011; Coughlan et al., 2016). Therefore, for effective control of bacteria on the technological equipment of the meat processing industry with the help of disinfectants and detergents, evoke the necessity to study their effect on bacteria formed in biofilms.

The results of studies on the influence of the "Sanactive" on conditionally pathogenic microorganisms that are formed in the biofilm are given in Table. 3 .

As can be seen from Table. 3, the "San-active" agent at $0.1 \%$ concentration did not exhibit bactericidal action on the conditionally pathogenic microorganisms present in the formed biofilm, even within 30 minutes of exposition. According to table 3 , this concentration of the agent provided bactericidal action for 20 minutes of exposure to all conditionally pathogenic microorganisms in planktonic form, indicating an increased resistance of bacteria that are formed in a biofilm. 
Table 3

Influence of "San-active" on conditional pathogenic microorganisms that are formed in a biofilm at a temperature of $60 \pm 5{ }^{\circ} \mathrm{C}$, $\mathrm{n}=20$

\begin{tabular}{|c|c|c|c|c|c|c|c|c|c|}
\hline \multirow{4}{*}{ Researched agent } & \multirow{4}{*}{$\begin{array}{c}\text { Concentration, } \\
\%\end{array}$} & \multicolumn{8}{|c|}{ Test cultures of microorganisms which are formed in biofilms } \\
\hline & & \multirow{2}{*}{\multicolumn{2}{|c|}{ S. aureus }} & \multicolumn{2}{|c|}{ E. faecalis } & \multicolumn{2}{|c|}{ E. coli } & \multicolumn{2}{|c|}{$P$. aeruginosa } \\
\hline & & & & \multicolumn{6}{|c|}{ Duration of an action, min. } \\
\hline & & 10 & 30 & 10 & 30 & 10 & 30 & 10 & 30 \\
\hline \multirow{4}{*}{ San-active } & 0.1 & - & - & - & - & - & - & - & - \\
\hline & 0.5 & + & + & + & + & - & + & - & + \\
\hline & 1.0 & + & + & + & + & + & + & + & + \\
\hline & 1.5 & + & + & + & + & + & + & + & + \\
\hline \multicolumn{2}{|c|}{ Control (Distilled water) } & - & - & - & - & - & - & - & - \\
\hline
\end{tabular}

The "San-active" agent at $0.5 \%$ concentration provided an inhibitory effect on bacteria $S$. aureus and E. faecalis for 10 minutes of actions. However, a ten-minute exposure at such a concentration did not provide complete bactericidal action on E. coli and $P$. aeruginosa cultures present in the biofilm. In order to achieve the death of the bacteria of the Pseudomonas aeruginosa and E. coli, which are in the biofilm, it is necessary that the working solution of the "Sanactive" agent should be at a concentration of not less than $0.5 \%$ at an exposure of not less than 30 minutes.

A slight difference in bactericidal concentration and exposure to microorganisms, which are both in planktonic form and formed in a biofilm, is explained by the high alkalinity of the working solutions of the agent with a $\mathrm{pH}$ of 12 and more units, as well as a high temperature of $60 \pm 5{ }^{\circ} \mathrm{C}$. The presence of alkali in the "San-active" and its use at high temperature provides hydrolysis and temperature denaturation of the matrix of biofilms, while the disinfectant of the catamenium $\mathrm{AB}$ exhibits bactericidal action.

Thus, the conducted researches indicate that the developed agent "San-active" can be used for neutralization of conditionally pathogenic bacteria, spore-forming and fungal microflora on the surfaces of objects of the meat processing industry in the concentration of working solutions of $0.5 \%$ and above $60 \pm 5{ }^{\circ} \mathrm{C}$ and exposure not less than 30 minutes.

Washing-disinfectants, used in the meat and dairy industry, in addition to bactericidal action, should have a good washing effect on the mark well or excellent.

The study of the washing properties of the "San-active" was carried out in laboratory conditions. The agent was used at concentrations from 0.1 to $1.5 \%$ (Table 4 ).

Table 4

Washing capacity of the "San-active", $n=12$

\begin{tabular}{lccc}
\hline \multicolumn{1}{c}{ Name of the agent } & $\begin{array}{c}\text { Temperature of the working } \\
\text { solution, }{ }^{\circ} \mathrm{C}\end{array}$ & $\begin{array}{c}\text { Concentration of washing- } \\
\text { disinfecting agents }\end{array}$ & Evaluation of washing effect \\
\hline & & 0.1 & Good \\
San-active & $60 \pm 5$ & 0.5 & Good \\
& & 1.0 & Excellent \\
Excellent \\
Chloranthine
\end{tabular}

As can be seen from Table. 4, the "San-active" agent at a concentration of $0.1-0.5 \%$ showed a good washing effect, and starting from $1.0 \%$ concentration - excellent. Consequently, the results indicated that, in order to provide an excellent washing effect of technological equipment at meat industry enterprises, the concentration of the "San-active" should not be lower than $1.0 \%$.

At present, in meat processing enterprises, technological equipment mainly consist of stainless steel (Al-Adawi et al., 2016). Therefore, when developing the means for sanitary treatment of processing equipment, it is important to study the corrosion activity of such means for metal surfaces (Okafor et al., 2009).

Working solutions of detergents or disinfectants should not cause corrosion of metal parts of equipment for more than $2.0 \mathrm{~g} / \mathrm{m}^{2}$-year (corrosion rate), for stainless steel $6.0 \mathrm{mg} / \mathrm{m}^{2}$-hour.

Solutions of the "San-active" from 1.0 to $2.0 \%$ concentration exhibited a slight corrosion activity on stainless steel, which ranged from 0.01 to $0.03 \mathrm{~g} / \mathrm{m}^{2}$-year, which, respectively, was 200 and 66 times is smaller, compared to allowable indicators (Table 5).

The corrosion speed rate of $1.0-2.0 \%$ of solutions of the "San-active" did not exceed $0.16 \mathrm{mg} / \mathrm{m}^{2}$-year. This indicated the possibility of its use for sanitary processing of technological equipment without damaging the working surfaces.

Production testing of sanitary processing of technological equipment in the intestinal workshop was carried out by the "San-active" washing-disinfectant according to the following scheme:

- rinsing the equipment with warm water at a temperature of $40-50{ }^{\circ} \mathrm{C}$ using the automatic device Karcher;

- hand washing with $0.5-2.0 \%$ solution of the detergent "San-active" at a temperature of $60 \pm 5^{\circ} \mathrm{C}$ for 20 minutes;

- the final rinse with water at a temperature of $40-50{ }^{\circ} \mathrm{C}$ with the help of the automatic device Karcher. 
Table 5

Corrosive action of solutions of detergent "San-active" on stainless steel, $M \pm m, n=9$

\begin{tabular}{|c|c|c|c|c|c|}
\hline \multirow{2}{*}{ Name of the agent } & \multirow{2}{*}{$\begin{array}{l}\text { Concentration of } \\
\text { solutions of } \\
\text { agents, } \%\end{array}$} & \multicolumn{2}{|c|}{ Mass of samples } & \multirow{2}{*}{$\begin{array}{l}\text { Size of corro- } \\
\text { sion, } \mathrm{g} / \mathrm{m}^{2} \text {-year }\end{array}$} & \multirow{2}{*}{$\begin{array}{l}\text { Speed of corro- } \\
\text { sion, } \mathrm{mg} / \mathrm{m}^{2}- \\
\text { hours }\end{array}$} \\
\hline & & Initial & in $182,5 \mathrm{~h}$. & & \\
\hline \multirow{3}{*}{ San-active } & 1.0 & $2.625 \pm 0.001$ & $2.624 \pm 0.001$ & 0.01 & 0.05 \\
\hline & 1.5 & $2.644 \pm 0.001$ & $2.642 \pm 0.002$ & 0.02 & 0.1 \\
\hline & 2.0 & $2.620 \pm 0.002$ & $2.617 \pm 0.002$ & 0.03 & 0.16 \\
\hline Chloranthine & 0.3 & 2.515 & 2.513 & 0.02 & 0.1 \\
\hline
\end{tabular}

Notes: norm - size of corrosion - $2.0 \mathrm{~g} / \mathrm{m}^{2}$-year; speed of corrosion $-6.0 \mathrm{mg} / \mathrm{m}^{2}$-hour

At the end of the sanitary treatment, the abovementioned scheme removed the equipment from the equipment for microbiological examination and the detection of residues of the detergent on its surface. On the average, the microbial number of washes from the working surfaces of equipment in the intestinal workshop, after the completion of the technological process, was $10^{6}-10^{8} \mathrm{CFU} / \mathrm{cm}^{3}$ (Table 6).

Conducting sanitation using "San-active" at a concentration of $0.5 \%$ contributed to a decrease in the number of microorganisms by $99.8-99.9 \%$. The microbial number of washes was $(4.3 \pm 0.22) \cdot 10^{3}-(1.3 \pm 0.1) \cdot 10^{4} \mathrm{CFU} / \mathrm{cm}^{3}$, depending on the type of equipment. The given amount of microflora on the equipment exceeded the microbiological standard of purity $\left(1000 \mathrm{CFU} / \mathrm{cm}^{3}\right.$ per $100 \mathrm{~cm}^{2}$ of area). Sanitary treatment with a $1.0 \%$ concentration provided a reduction of $99.9 \%$ of microorganisms, and their amount in washings was $(1.7-5.7) \cdot 10^{2} \mathrm{CFU} / \mathrm{cm}^{3}$, for the titre $\mathrm{BGKP} \geq 1$. For $1.5-2.0 \%$ concentration of working solutions of the agent - sanitation efficiency was $100 \%$.

\section{Table 6}

Microbiological indicators of washings out of technological equipment in the intestinal workshop using the "San-active", $\mathrm{M} \pm \mathrm{m}, \mathrm{n}=16$

\begin{tabular}{|c|c|c|c|c|c|c|}
\hline \multirow[b]{2}{*}{$\begin{array}{l}\text { Solution concen- } \\
\text { tration, } \%\end{array}$} & \multirow[b]{2}{*}{$\begin{array}{c}\text { Research } \\
\text { object }\end{array}$} & \multicolumn{2}{|c|}{ Before processing } & \multicolumn{2}{|c|}{ After processing with "San-active" } & \multirow[b]{2}{*}{$\begin{array}{l}\text { Efficiency of } \\
\text { processing, \% }\end{array}$} \\
\hline & & $\begin{array}{l}\mathrm{MW}, \mathrm{CFU} / \mathrm{cm}^{3} \text { of } \\
\text { flush }\end{array}$ & $\begin{array}{l}\text { the title of } \\
\text { BGKP }\end{array}$ & $\begin{array}{l}\mathrm{MW}, \mathrm{CFU} / \mathrm{cm}^{3} \text { of } \\
\text { flush }\end{array}$ & $\begin{array}{l}\text { the title of } \\
\text { BGKP }\end{array}$ & \\
\hline \multirow{4}{*}{0,5} & 1 & $(6.7 \pm 0.41) \cdot 10^{6}$ & $0.001-0.01$ & $(1.3 \pm 0.10) \cdot 10^{4 *}$ & $0.1-1$ & 99.8 \\
\hline & 2 & $(5.9 \pm 0.37) \cdot 10^{6}$ & $0.1-1$ & $(7.3 \pm 0.4) \cdot 10^{3 *}$ & $\geq 1$ & 99.9 \\
\hline & 3 & $(7.3 \pm 0.47) \cdot 10^{7}$ & $0.1-1$ & $(4.6 \pm 0.30) \cdot 10^{3 *}$ & $\geq 1$ & 99.9 \\
\hline & 4 & $(8.8 \pm 0.56) \cdot 10^{8}$ & $0.1-1$ & $(4.3 \pm 0.22) \cdot 10^{3 *}$ & $\geq 1$ & 99.9 \\
\hline \multirow{4}{*}{1,0} & 1 & $(3.8 \pm 0.60) \cdot 10^{7}$ & $0.001-0.01$ & $(3.2 \pm 0.16) \cdot 10^{2 *}$ & $0.1-1$ & 99.9 \\
\hline & 2 & $(7.4 \pm 0.47) \cdot 10^{6}$ & $0.1-1$ & $(4.3 \pm 0.23) \cdot 10^{2 *}$ & $\geq 1$ & 99.9 \\
\hline & 3 & $(2.1 \pm 0.15) \cdot 10^{7}$ & $0.1-1$ & $(1.7 \pm 0.1) \cdot 10^{2 *}$ & $\geq 1$ & 99.9 \\
\hline & 4 & $(7.1 \pm 0.50) \cdot 10^{7}$ & $0.1-1$ & $(5.7 \pm 0.30) \cdot 10^{2 *}$ & $\geq 1$ & 99.9 \\
\hline \multirow{4}{*}{1,5} & 1 & $(5.1 \pm 0.38) \cdot 10^{6}$ & $0.001-0.01$ & $(1.1 \pm 0.10) \cdot 10^{1 *}$ & $0.1-1$ & 99.9 \\
\hline & 2 & $(7.2 \pm 0.51) \cdot 10^{5}$ & $0.1-1$ & 0 & $\geq 1$ & 100 \\
\hline & 3 & $(8.6 \pm 0.56) \cdot 10^{6}$ & $0.1-1$ & $(1.4 \pm 0.10) \cdot 10^{1 *}$ & $\geq 1$ & 99.9 \\
\hline & 4 & $(6.7 \pm 0.39) \cdot 10^{7}$ & $0.1-1$ & $(7.2 \pm 0.4) \cdot 10^{1 *}$ & $\geq 1$ & 99.9 \\
\hline \multirow{4}{*}{2,0} & 1 & $(4.5 \pm 0.23) \cdot 10^{8}$ & $0.001-0.01$ & 0 & $0.1-1$ & 100 \\
\hline & 2 & $(3.9 \pm 0.17) \cdot 10^{6}$ & $0.1-1$ & 0 & $\geq 1$ & 100 \\
\hline & 3 & $(4.2 \pm 0.14) \cdot 10^{7}$ & $0.1-1$ & 0 & $\geq 1$ & 100 \\
\hline & 4 & $(3.1 \pm 0.21) \cdot 10^{8}$ & $0.1-1$ & $(1.2 \pm 0.1) \cdot 10^{1 *}$ & $\geq 1$ & 99.9 \\
\hline \multirow{3}{*}{ Chloranthine 0,3} & 1 & $(5.6 \pm 0.35) \cdot 10^{5}$ & $0.001-0.01$ & $(2.7 \pm 0.18) \cdot 10^{3 *}$ & 1 & 99.5 \\
\hline & 2 & $(4.7 \pm 0.24) \cdot 10^{7}$ & $0.1-1$ & $(9.4 \pm 0.61) \cdot 10^{4 *}$ & $\geq 1$ & 99.8 \\
\hline & 3 & $(4.7 \pm 0.21) \cdot 10^{6}$ & $0.1-1$ & $(7.3 \pm 0.51) \cdot 10^{4 *}$ & $\geq 1$ & 98.4 \\
\hline
\end{tabular}

Notes: * $-\mathrm{P} \leq 0,001-$ in comparison to the number of microorganisms before sanitation processing; Table for the separation of intestines; 2 - Tables of different purposes; 3 - Tanks of different purpose; 4 - Intestine cleaning machine

The use of the "Chloranthine" did not ensure the proper cleanliness of the surfaces of the technological equipment according to the norms. Its effect is similar to the use of $0.5 \%$ solution of the "San-active".

Thus, the obtained results indicate that the use of "Sanactive" detergent from 1.0 to $2.0 \%$ concentration at a temperature of $60 \pm 5{ }^{\circ} \mathrm{C}$, an exposure of 20 minutes and a rinsing with an automatic device Karcher provides for 99.9$100 \%$ efficiency of sanitary treatment in the intestinal shop.

\section{Conclusions}

1. "San-active" disinfectant in the concentration from 0.3 to $2.5 \%$ is fast-dissolving in water, from moderately to very alkaline, and surface tension, wettability and foaming ability meet the requirements for facilities for sanitary processing of technological equipment for the meat industry.

2. The "San-active" agent in $0.5 \%$ concentration provides a bactericidal effect on test cultures of conditionallypathogenetic bacteria: S. aureus, E. faecalis, E. coli, P. aeruginosa (for $10 \mathrm{~min}$ ); spore-forming microflora $B$. cereus and B. subtillis (after $30 \mathrm{~min}$ ); on fungi of genus Penicillium spp. (after $20 \mathrm{~min}$ ) and Candida spp. (after 10 minutes).

3. The "San-active" agent has a washing effect for the mark "good" at $0.5 \%$ concentration, and $1.0 \%$ and above is rated "excellent". In 1.0-2.0\% of concentration shows a slight corrosion activity on stainless steel, which is $200-66$ times lower than the permissible norm.

4. The use of "San-active" detergent from 1.0 to $2.0 \%$ concentration, at a temperature of $60 \pm 5{ }^{\circ} \mathrm{C}$, exposure of 
20 minutes and rinsing with water using an automatic device Karcher, provides $99.9-100 \%$ the efficiency of sanitary treatment in the intestinal shop.

In the future, the normative and technical documentation for the created agent for introduction into production will be developed and agreed upon.

\section{References}

Jessen, B., \& Lammert, L. (2003). Biofilm and disinfection in meat processing plants. International biodeterioration \& biodegradation, 51(4), 265-269. doi: 10.1016/S0964-8305(03)00046-5.

Sun, D.W. (2014). Emerging technologies for food processing. 2th ed. Elsevier.

Marriott, N.G., Schilling, M.W., \& Gravani, R.B. (2018). Principles of food sanitation. 6th ed. Springer. doi: 10. 1007/978-3319-67166-6.

Abdallah, M., Benoliel, C., Drider, D., Dhulster, P., \& Chihib, N.E. (2014). Biofilm formation and persistence on abiotic surfaces in the context of food and medical environments. Archives of Microbiology, 196(7), 453-472. doi: 10.1007/s00203-0140983-1.

Kukhtyn, M., Berhilevych, O., Kravcheniuk, K., Shynkaruk, O., Horyuk, Y., \& Semaniuk, N. (2017). The influence of disinfectants on microbial biofilms of dairy equipment. "EUREKA: Life Sciences", 5, 11-17. doi: 10.21303/2504-5695.2017.00423.

Bekker, J.L., Hoffman, L.C., \& Jooste, P.J. (2011). Knowledge of stakeholders in the game meat industry and its effect on compliance with food safety standards. International Journal of Environmental Health Research, 21(5), 341-363. doi: 10.1080/09603123.2011.552715.

Varzakas, T., \& Tzia, C. (2015). Handbook of food processing: food safety, quality, and manufacturing processes. CRC Press.

Kukhtyn, M., Berhilevych, O., Kravcheniuk, K., Shynkaruk, O., \& Horyuk, Y. (2017). Formation of biofilms on dairy equipment and the influence of disinfectants on them. Eastern-European Journal of Enterprise Technologies, 5, 11(89), 26-33. doi: 10.15587/1729-4061.2017.110488.

Kovalenko, V.L., Kovalenko, P.L., Ponomarenko, G.V., Kukhtyn, M.D., Midyk, S.V., Horiuk, Y.V. et al. (2018). Changes in lipid composition of Escherichia coli and Staphylococcus areus cells under the influence of disinfectants Barez ${ }^{\circledR}$, Biochlor ${ }^{\circledR}$ and Geocide ${ }^{\circledR}$. Ukrainian Journal of Ecology, 18, 8(1), 547-550. doi: $10.15421 / 2018248$

Knape, L., Hambraeus, A., \& Lytsy, B. (2015). The adenosine triphosphate method as a quality control tool to assess 'cleanliness' of frequently touched hospital surfaces. Journal of Hospital Infection, 91(2): 166-170. doi: 10.1016/j.jhin.2015.06.011.

Meireles, A., Giaouris, E., \& Simoes, M. (2016). Alternative disinfection methods to chlorine for use in the fresh-cut industry. Food Research International, 82, 71-85. doi: 10.1016/j.foodres.2016.01.021.

Da Costa Luciano, C., Olson, N., Tipple, A.F.V., \& Alfa, M. (2016). Evaluation of the ability of different detergents and disinfectants to remove and kill organisms in traditional biofilm. American journal of infection control, 44(11), 243-249. doi: 10.1016/j.ajic.2016.03.040.
Le Maire, M., Champeil, P., \& Moller, J.V. (2000). Interaction of membrane proteins and lipids with solubilizing detergents. Biochimica et Biophysica Acta (BBA)-Biomembranes, 1508(1), 86-111. doi: 10.1016/S0304-4157(00)00010-1.

Seddon, A.M., Curnow, P., \& Booth, P.J. (2004). Membrane proteins, lipids and detergents: not just a soap opera. Biochimica et Biophysica Acta (BBA)-Biomembranes, 1666(1), 105-117. doi: 10.1016/j.bbamem.2004.04.011.

Kowalska, I. (2016). Concentration of contaminated single-phase detergents by means of unit and integrated membrane processes. Separation Science and Technology, 51(7), 1199-1209. doi: 10.1080/01496395.2016.1146298.

Cazelle, E., Eskes, C., Hermann, M., Jones, P., McNamee, P., Prinsen, M. et al. (2015). Suitability of the isolated chicken eye test for classification of extreme $\mathrm{pH}$ detergents and cleaning products. Toxicology In Vitro, 29(3), 609-616. doi: 10.1016/j.tiv.2014.12.020

Li, L., Abild-Pedersen, F., Greeley, J., \& Norskov, J.K. (2015). Surface tension effects on the reactivity of metal nanoparticles. The journal of physical chemistry letters, 6(19), 3797-3801. doi: 10.1021/acs.jpclett.5b01746.

Yao, L., \& He, J. (2014). Recent progress in antireflection and selfcleaning technology-From surface engineering to functional surfaces. Progress in Materials Science, 61, 94-143. doi: 10.1016/j.pmatsci.2013.12.003.

Burmolle, M., Webb, J.S., Rao, D., Hansen, L.H., Sorensen, S.J., \& Kjelleberg, S. (2006). Enhanced biofilm formation and increased resistance to antimicrobial agents and bacterial invasion are caused by synergistic interactions in multispecies biofilms. Appl. Environ. Microbiol, 72, 3916-3923. doi: 10.1128/aem.03022-05.

Langsrud, S., Moen, B., Moretro, T., Loype, M., Heir, E. (2016). Microbial dynamics in mixed culture biofilms of bacteria surviving sanitation of conveyor belts in salmon-processing plants. Journal of applied microbiology, 120(2), 366-378. doi: 10.1111 jam.13013.

Moretro, T., \& Langsrud, S. (2017). Residential bacteria on surfaces in the food industry and their implications for food safety and quality. Comprehensive Reviews in Food Science and Food Safety. 16(5), 1022-1041. doi: 10.1111/15414337.12283.

Abee, T., Kovacs, A.T., Kuipers, O.P., \& van der Veen, S. (2011). Biofilm formation and dispersal in Gram-positive bacteria. Curr. Opin. Biotechnol, 22, 172-179. doi: 10.1016/j.copbio.2010.10.016.

Coughlan, L.M., Cotter, P.D., Hill, C., \& Alvarez-Ordonez, A. (2016). New weapons to fight old enemies: novel strategies for the (bio) control of bacterial biofilms in the food industry. Frontiers in microbiology, 7, 1641. doi: 10.3389/fmicb.2016.01641.

Al-Adawi, A.S., Gaylarde, C.C., Sunner, J., \& Beech, I.B. (2016). Transfer of bacteria between stainless steel and chicken meat: a CLSM and DGGE study of biofilms. AIMS Microbiol, 2, 340 358. doi: 10.3934/microbiol.2016.3.340.

Okafor, P.C., Uwah, I.E., Ekerenam, O.O., \& Ekpe, U.J. (2009). Combretum bracteosum extracts as eco-friendly corrosion inhibitor for mild steel in acidic medium. Pigment \& Resin Technology, 38(4), 236-241. doi: 10.1108/03699420910973323. 